
\title{
CIÊNCIANATURA
}

\section{Environmental Licensing Challenges of Xingu Rio Transmission System Route Definitions}

Ricardo A. F. Cardoso Jr., D.Sc. ${ }^{1}$ and Alessandra S. Hoffmann, B. Sc. ${ }^{2}$

${ }^{1}$ Agriculture and Environmental Engineering Department - Engineering School. Fluminense Federal University. Niterói - RJ, Brazil

${ }^{2}$ Water Resources and Environmental Engineering Department - Engineering School. Fluminense Federal University.

\begin{abstract}
Based on the Brazilian electric sector planning, by 2026 the transmission grid will be increased by 64 thousand km, so that the analysis of how to incorporate the environmental criteria in the discussions of route optimization are important for the decision-making of the various actors (government, environmental agencies and entrepreneurs). Therefore, this article aims to identify the challenges of the incorporation of the socio-environmental criteria for the route optimization as well as the deadlines and costs of the Xingu-Rio Transmission System known to be the largest transmission system in Brazil.
\end{abstract}

Keywords: Environmental factors; Environmental licensing; Brazil; Transmission lines 


\section{Introduction}

According to Abotah \& Daim (2017), a relevant part of the future renewable electricity generation would come from distant sources, meaning that grid improvements such as increases in the transmission capacity are critical for a successful connection of these sources into the grid.

By Decennial Energy Expansion Plan 2026 (Plano Decenal de Expansão de Energia - PDE), the Brazilian electric sector planning must increase its electric power transmission infrastructure in the metric of $3.1 \%$ per year in order to generate reliability for the growing consumption demand. The same study shows that by 2026 Brazil will increase about 64 thousand $\mathrm{km}$ of power transmission infrastructure comparing to 2016.

Nowadays, the expansion of the electric power transmission infrastructure has several international entrepreneurs, participating in public concessions in Brazil. Even the Brazilian electric sector being well regulated by standards, obstacles and uncertainties are still observed in the environmental licensing rite, causing mistrust as well as risks.

As there is a big distance between the region with the highest potential for power generation and the region with the highest energy consumption, it's important to discuss the route of the transmission systems, looking for a sustainable way to expand the grid. According to Akinyele \& Rayudu (2016), the concept of sustainability has traditionally been considered from the viewpoints of social, economical and environmental aspects.

Several authors (Bonatto, 2004; Campos, 2010; Cardoso Jr., 2014; De Castro et al., 2012; Santos, 2017) discuss the environmental criteria and associated risks for optimized definition of routes for transmission systems that incorporate the Environmental Impact Assessment.

Thus, the present article seeks to answer the following question:

What is the main environmental criteria that should be analyzed in order to include the environment in the discussion of route optimizations?

For such task, this article will first present the main environmental frameworks and the relationship among the different actors. In sequence, it will show the Brazilian Environmental Legal Marks, and finally it will present the socio-environmental criteria for the route optimization and a case study.

The case in question will point out the main challenges in the planning stage of the largest Brazilian transmission system, the Xingu-Rio Transmission System, as it evaluates the incorporation of socio-environmental criteria for route optimization, in addition to deadlines and costs. This system is responsible for interconnecting Belo Monte Hydroelectric Power Plant, in the state of Pará, and the state of Rio de Janeiro, for more than 2,550 km of extension in HVDC $800 \mathrm{kV}$.

\subsection{Research Goals}

The paper proposes to identify the challenges of the incorporation of the socio-environmental criteria for route optimization of the Xingu-Rio Transmission System, referred to as the largest transmission system in Brazil, with 2,550 km of extension in HVDC $800 \mathrm{kV}$ as well as its deadlines and costs.

\section{Materials and Methods}

In order to achieve the expected results, the present work is based on an exploratory research of the regulatory and procedural milestones of the environmental licensing rite and of the Brazilian electric sector, as well as bibliographic research.

\section{Results and Discussion}

\subsection{Actors and relationships}

The implementation of transmission systems imposes the need for a relationship among several actors, including environmental licensing agency, intervening agencies and other entities, where their competencies and responsibilities are taken into consideration, described and presented in Figure 1. 
Figure 1 - Reliability analysis

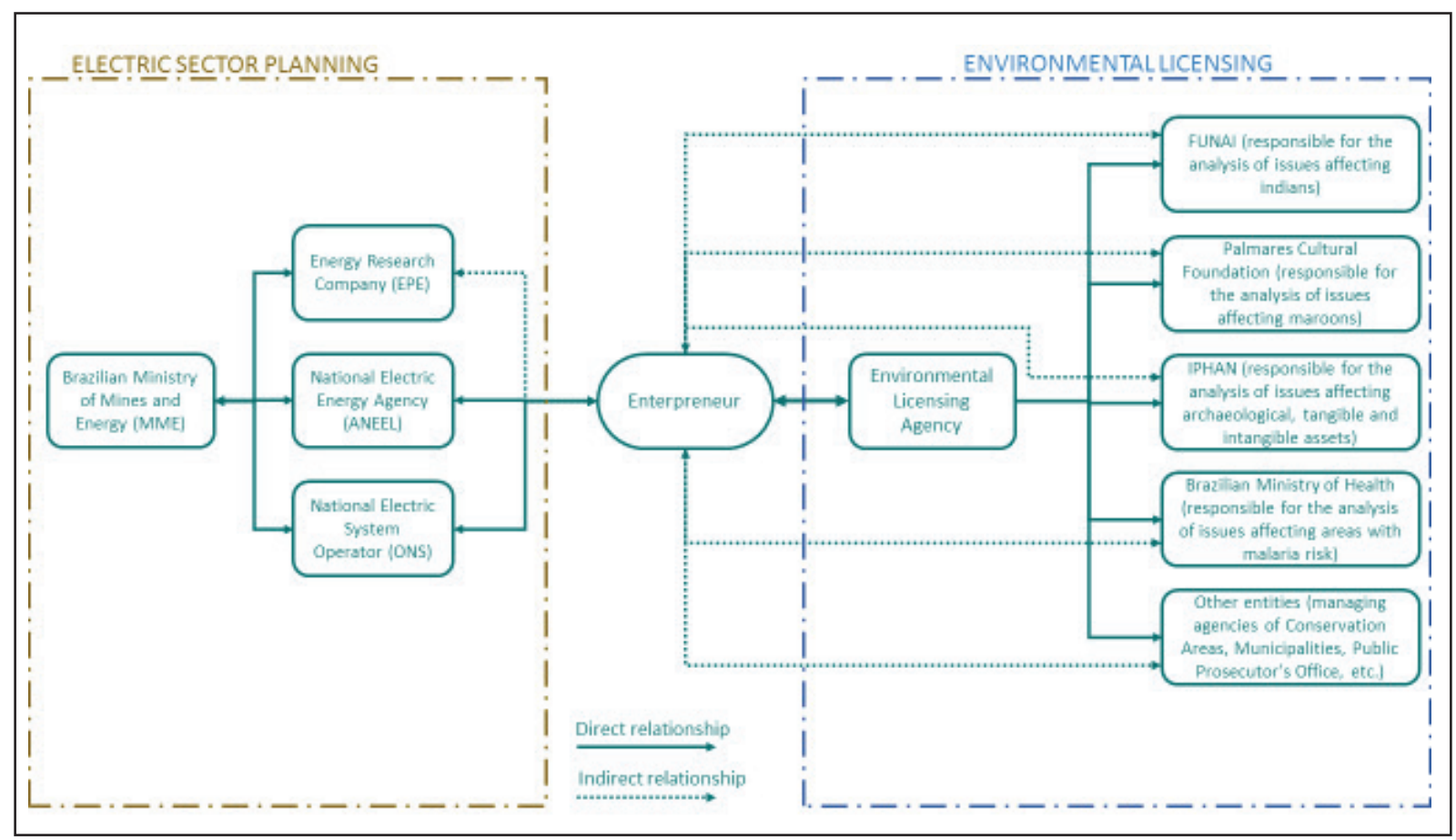

Source: Authors

Among the actors associated with environmental licensing, the entrepreneur, responsible for the concession contractual service, the development of the environmental studies and the project, implementation, operation and maintenance of the concession, is directly related to the environmental licensing agency and indirectly with other agencies, whose attributions and competencies are described below:

- Environmental licensing agency, responsible for the environmental studies analysis, as well as for the granting of the environmental licenses. It is directly related to the entrepreneur and to the other agencies;

- Intervening agencies, responsible for environmental licensing specificities, such as (a) FUNAI whose themes are associated with Indians, (b) Palmares Cultural Foundation whose themes are associated with Quilombolas, (c) IPHAN, whose themes are related to the defense of archaeological, tangible and intangible assets, as well as (d) The Brazilian Ministry of Health, responsible for topics related to the prevention of endemic diseases such as Malaria;

- Other entities, (a) Managing agencies of conservation areas, responsible for territorial management and authorization of interference with these protected areas; (b) the municipalities crossed by the venture that must manifest themselves as to the route of the venture in relation to the territorial planning, in accordance with land use and occupation; (c) Public Prosecutor's Office, which defends the interests of society, etc.

- However, it is also up to the entrepreneur to directly relate to the electric sector agencies, such as (i) the National Electric Energy Agency (Agência Nacional de Energia Elétrica - ANEEL), which regulates the Brazilian electric sector, and (ii) the National Electric System Operator (Operador Nacional do Sistema Elétrico - ONS) responsible for coordinating and controlling the generation and transmission of electricity in the National Interconnected System.

Indirectly, the entrepreneur relates to the Energy Research Company (Empresa de Pesquisa Energética - EPE), responsible for carrying out studies to subsidize the energy sector planning. According to Law 10847/04, article 4, EPE is responsible for initiating the necessary studies to obtain the Preliminary License, before the concession of electricity generation and transmission ventures.

\subsection{Environmental Legal Marks}

Below are the main environmental legal marks, which dictate the mandatory studies required, focusing on environmental impact assessment and environmental licensing. 


\subsubsection{Environmental Impact Assessment}

The Environmental Impact Assessment (EIA) is an important instrument for the decision-making process, since it previously diagnoses the environmental status in the area of influence where the venture is intended to be implemented and compares it with the forecast of possible changes in the environmental quality.

Several authors (Abotah \& Daim, 2017; Bolea, 1984; Cardoso Jr., 2014; Magrini, 1990; Moreira, 1985; Oliveira, 2005; Wathern, 1988) agree about the importance of the Environmental Impact Assessment in the decision-making process regarding the authorization for the implementation of polluting ventures.

According to the Brazilian Federal Law 6938 of 1981, the Environmental Impact Assessment is an instrument of the National Environmental Policy. However, the regulation of EIA in Brazil occurred only after the publication of CONAMA Resolution 01/1986 in which, for example, it was defined that for electric power transmission ventures with voltage from 230 $\mathrm{kV}$ on, environmental impact studies must be carried out before their implementation.

The direct influence of the European Union Directive 85/337/EEC can be observed, as it was published in 1985 (one year before CONAMA Resolution 01/1986), and it defined which typologies of ventures should result in the environmental impact studies. In particular, for the transmission lines, this Directive defined the voltage (above $220 \mathrm{kV}$ ) and extension (greater than $15 \mathrm{~km}$ ) as the criteria for conducting such studies. Due to the continental dimensions of Brazil, the $15 \mathrm{~km}$ extension criterion would not be relevant.

However, the Environmental Impact Assessment alone could not produce great results without the regulation of a procedural authoritative rite. The Environmental Licensing regulation lacked in Brazil. Thus, according to Milaré (2001), the Decree 88.351/1983, which regulated the Law 6938/1981 and was revoked by the Decree 99.247/1990, was the great responsible for associating the Environmental Impact Assessment with the Environmental Licensing procedure.

\subsubsection{Environmental Licensing and its updates}

The CONAMA Resolution 237/1997 regulated the Brazilian Environmental Licensing procedure (11 years after the EIA regulation from CONAMA Resolution 01/1986), outlining competencies, deadlines and procedures. Three (3) types of environmental licenses and their respective procedural frameworks were defined, namely:

- Preliminary License (Licença Prévia - LP): Granted in the planning phase of the venture, approving its location and design, attesting its environmental viability;

- Installation License (Licença de Instalação - LI): Authorizes the venture installation according to the specifications contained in the approved plans, programs and projects, including the environmental control measures and other conditionings;

- Operation License (Licença de Operação - LO): Authorizes the venture operation, after compliance verification of previous licenses, with environmental control measures.

The Environmental Licensing rite was updated in 2011 from Supplementary Law 140/2011, Interministerial Ordinance 419/2011 (recently replaced by Interministerial Ordinance 60/2015), and a set of Ordinances from Brazil's Ministry of the Environment (Ministério do Meio Ambiente - MMA), as for instance the Ordinance MMA 421/2011.

According to Leme Machado (2013), the Complementary Law 140/2011 is a general norm that provides for the Union competence to legislate on general standards, not excluding the additional competence of States.

The Complementary Law 140/2011 adopted as a criterion for the impact location as a determining factor to define the competence for Environmental Licensing, replacing the impact coverage criterion previously defined by the CONAMA Resolution 237/1997 (Trennepohl \& Trennepohl, 2013).

Finally, one of the gains for the electric sector was the publication of MMA Ordinance 421/2011, issued by the Ministry of the Environment, establishing new rules for the Environmental Licensing at the federal level for the transmission ventures, in which simplified or ordinary procedures are determined, namely:

- Simplified, based on a "Simplified Environmental Report" (RAS);

- Ordinary, based on an "Environmental Assessment Report" (EAR) or on an "Environmental Impact Study" (EIS).

- For the transmission ventures framing as simplified environmental licensing, it should not involve, at least, the following:

- Population removal resulting in its non-viability;

- Interference with the Conservation Areas of Integral Protection;

- Interference with the reproduction and the rest sites of migratory bird routes;

- Intervention in the indigenous land and in quilombola territory;

- Intervention in natural caves;

- Suppression of native vegetation above $30 \%$ of the total area of the utility corridor;

- $\quad$ Extension exceeding $750 \mathrm{~km}$.

Simplified environmental licensing has provided interesting gains to society by reducing procedural deadlines comparing 
to the ordinary rite, so that the effort to carry out environmental studies in cases with less impact potential is reduced.

Comparing the deadlines established by MMA Ordinance 421/2011, the simplified procedure reduces the procedural time of studies analysis during the planning stage in approximately 15 months, increasing the celerity of the process, which undoubtedly is a procedural gain.

Finally, the two most recent updates in the environmental licensing rite are presented, being (i) the publication of Interministerial Ordinance 60/2015, which clearly regulates the role of intervening agencies (IPHAN, Palmares, Ministry of Health, FUNAI), also presenting standard Terms of Reference for conducting environmental studies by topic and deadlines, and (ii) the publication of Decree 8437/2015, which amends Complementary Law 140/2011, defining that the federal environmental licensing body (IBAMA), from of this act, has the authority to license ventures outside its jurisdiction, as long as the venture qualifies as a priority. The purpose of this regulation is to address the competence of the environmental licensing analysis to the most prepared entity, with the best technical team and infrastructure, while observing the legislator's concern in trying to expedite the environmental licensing rite.

\subsection{Challenges - Environmental Licensing of Xingu Rio Transmission System}

The analysis of the main challenges concerning the environmental licensing of the Xingu-Rio Transmission System will be divided into two themes: (i) associating the incorporation of socio-environmental criteria in route optimization, and (ii) deadlines and costs.

The importance of the venture is already evident in its characterization, with the Xingu Rio Transmission System being the largest in Brazil, responsible for interconnecting the Belo Monte Hydroelectric Power Plant in the state of Pará to the state of Rio de Janeiro. The transmission line extends for approximately 2,550 km in HVDC $800 \mathrm{kV}$, reinforcing the Southeast region, the main center of Brazilian cargo consumption, as seen in Figure 2.

\section{Figure 2 - Xingu-Rio Transmission System}

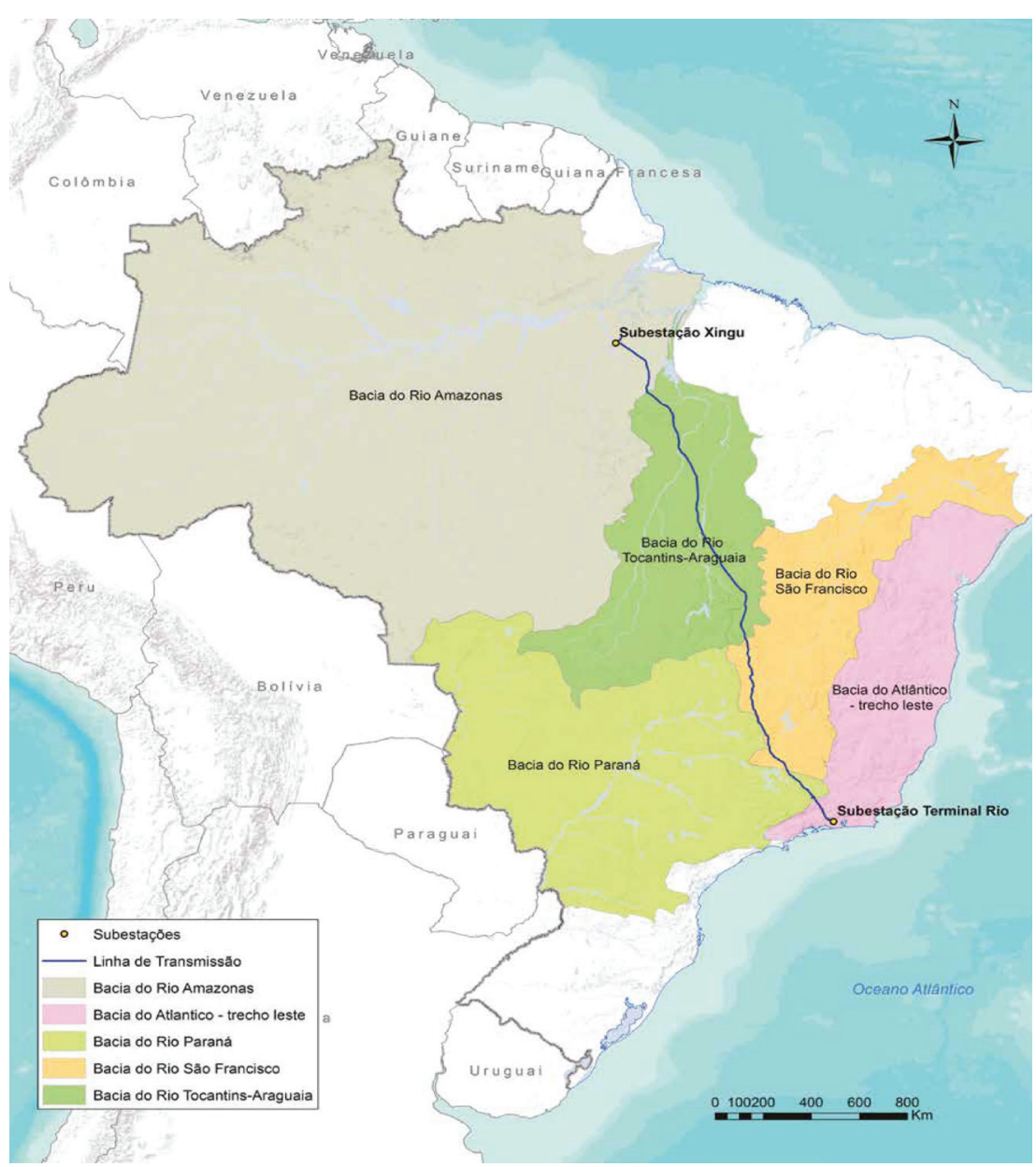




\subsubsection{Incorporation of socio-environmental criteria in route optimization}

Assuming that the main socio-environmental criteria is not known prior to the venture concession, since the environmental impact study only takes place after the auction, the route needs to be optimized in order to avoid or minimize the effects of relevant environmental aspects in an attempt to make the venture viable from the environmental point of view as of the issuance of the Preliminary License.

Table 1 below lists several socio-environmental criteria, relating their aspects and impacts, demonstrating the importance of avoiding or minimizing the interference on them. It should be noted that some of them are standardized as relevant to the framework for simplification of environmental studies by Ordinance MMA 421/2011.

Table 1 - Aspects X impacts X legislation. Source: Authors.

\begin{tabular}{|c|c|c|}
\hline Aspects & Impacts & Legislation \\
\hline Indigenous Lands & Interference with traditional communities & Interministerial Ordinance $60 / 2015$ \\
\hline Quilombola Communities & Interference with traditional communities & Interministerial Ordinance $60 / 2015$ \\
\hline Conservation Area & $\begin{array}{l}\text { Forest fragmentation, loss of habitat, change in } \\
\text { biodiversity }\end{array}$ & $\begin{array}{l}\text { Law 9985/2000, CONAMA Resolution } \\
\qquad 428 / 2010\end{array}$ \\
\hline Speleological Heritage (Caves) & Risk of damage to speleological heritage & CONAMA Resolution 347/2004 \\
\hline Forested areas & Forest fragmentation, loss of habitat, change in & Law $12651 / 2012$ \\
\hline Hydric bodies & Avoid affectation in sinuosities & $\begin{array}{l}\text { Law 12651/2012, CONAMA Resolution } \\
369 \\
\end{array}$ \\
\hline Settlements, improvements & Interference with productive areas, improvements & NBR $14653 / 2004$ \\
\hline $\begin{array}{l}\text { Permanent Preservation Area (Área de Preservação } \\
\text { Permanente - APP) }\end{array}$ & Interference with areas protected by law & $\begin{array}{l}\text { Law 12651/2012, CONAMA Resolution } \\
369\end{array}$ \\
\hline Archaeological Heritage & $\begin{array}{c}\text { Interference with archeological sites, tangible } \\
\text { and intangible assets }\end{array}$ & $\begin{array}{c}\text { Interministerial Ordinance } 60 / 2015, \text { IN } \\
\text { IPHAN } 01 / 2015\end{array}$ \\
\hline
\end{tabular}

Assuming a complete linearity between the Xingu and Rio Terminal substations, that is, without considering the socio-environmental criteria, the Xingu-Rio Transmission System would have an extension of approximately 2,326 km. However, this route is unlikely, different from the route whose venture was granted in June 2015, with a length of 2,518 km, already considering the avoidance of macro environmental interferences.

Figure 3 shows an example of non-affectation of indigenous land in the state of Pará, resulting in a variant of the venture route.

Figure 3- Route variant in white avoiding affectation of indigenous land. Source: Concremat (2016).

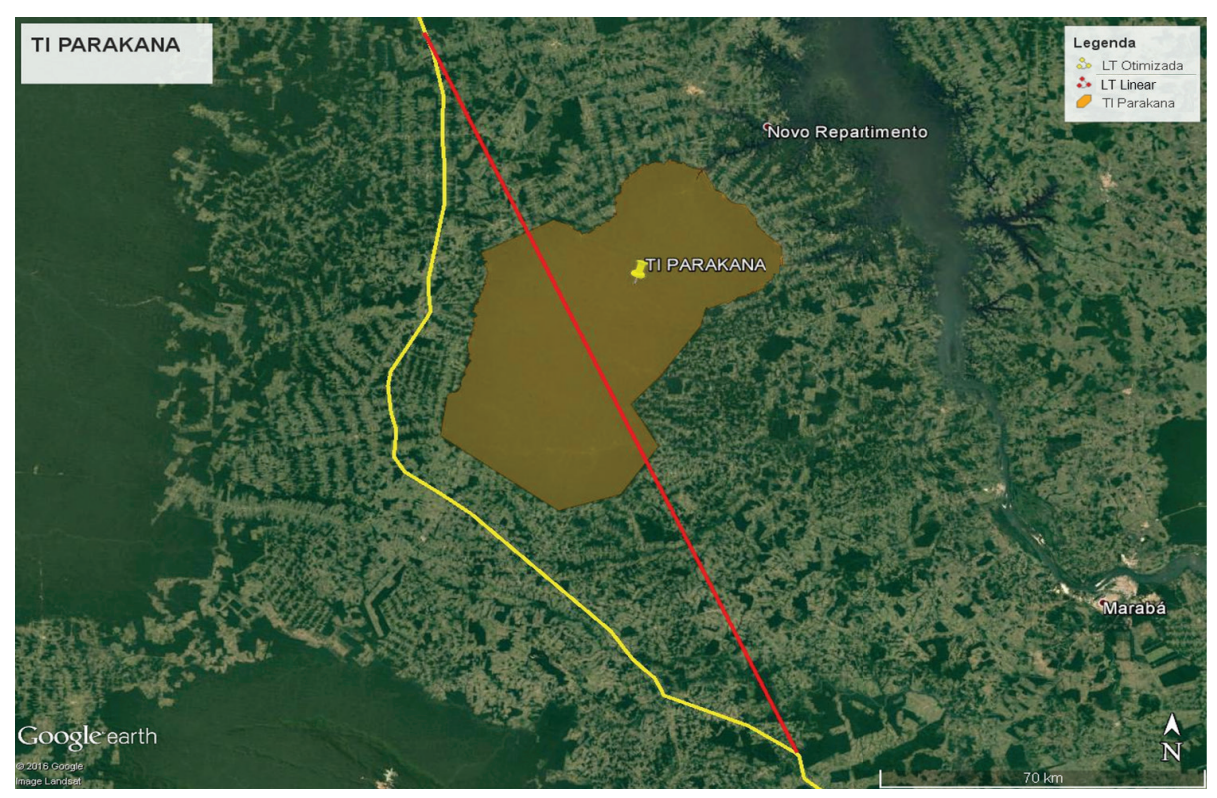


At the end of the environmental impact study, after the venture concession, by internalizing the necessary variants to avoid or minimize environmental impacts, the venture's extension was 2,534.6 km, that is, $16.6 \mathrm{~km}$ were added to the granted route.

Since the environmental licensing information is public, it was verified that the estimated cost to implement the venture is R \$ 7.63 billion (US\$ 2.42 billion), or approximately R \$ 3 million $/ \mathrm{km}$ (US\$ 0,95 million/ $/ \mathrm{km}$ of extension).

In a macro analysis, the environmental variables inclusion in the decision-making process, that made the venture route viable under the environmental aspect, increased by $16.6 \mathrm{~km}$ the extension of the venture, to the value of approximately R $3 \mathrm{million} /$ $\mathrm{km}$ (US\$ 0,95 million/ $\mathrm{km}$ ), which resulted in a cost increase for the entrepreneur of about R \$ 50 million (US\$ 15.9 million).

Such an increment in cost translates into a rise in the payback period, increasing the investment risk and reducing the attractiveness of this type of venture in the following ANEEL auctions.

If the environmental impact study had taken place prior to the concession, the main specificities and criticalities of the venture would already be known, as well as the contingencies foreseen by the entrepreneur for their conformity.

\subsubsection{Analysis of concession terms}

The Brazilian electric sector regulation defines the Permitted Annual Revenue (Receita Anual Permitida - RAP) as a remuneration modality for electricity transmission ventures. That is, after the venture concession by ANEEL, the entrepreneur must design, implement and make the venture available for operation, only receiving the RAP at the time when connected to the National Interconnected System, illustrated by Figure 4.

Figure 4 - National Interconnected System

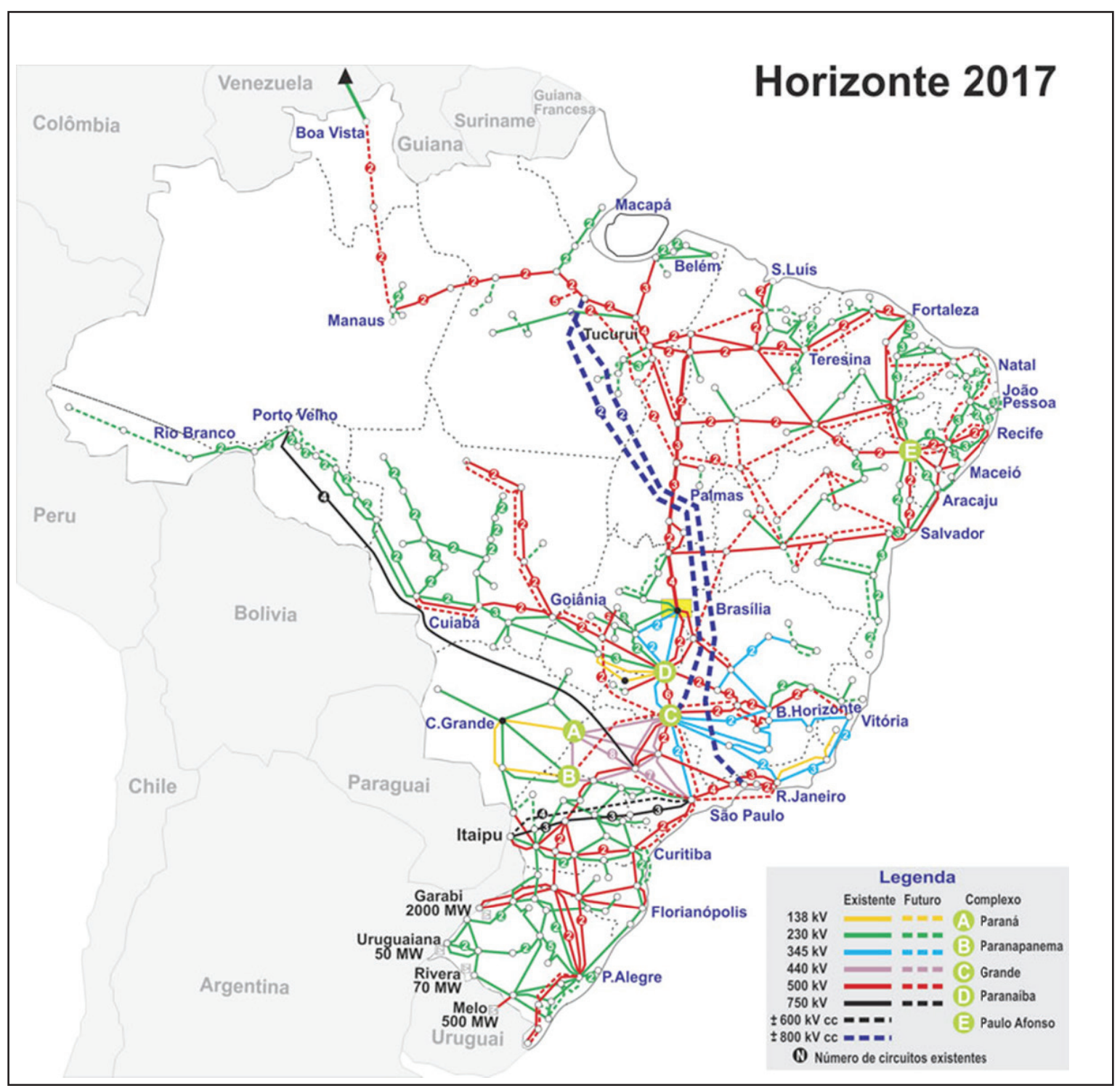

Source: National Electric System Operator (2017) 
In an analysis of the concession contract schedule of the Xingu-Rio Transmission System with ANEEL, it can be observed that it is expected that the venture starts the operation in 50 months starting on October 2015, that is, in December 2019.

To this end, the issuance of the Preliminary License (the one that demonstrates the venture environmental viability) was scheduled to be ready in 14 months and the Installation License (the one that authorizes the beginning of the works) in 18 months, so that in the remaining 32 months the venture could be implemented.

The Preliminary License for the venture was issued almost 17 months from the set date (adding up to nearly 3 months of delay compared with the scheduled) and the Installation License for part of the venture in 22 months (adding up 4 months of delay compared with the scheduled), having the remaining 28 months for the venture implementation.

This is aggravated by the fact that ANEEL had requested the anticipation of the start-up of this venture, due to the recent liabilities left by the projects not completed by the company ABENGOA, which entered into judicial recovery in 2016, representing to be a hard blow to the electric sector planning, as several priority projects were not completed. The National Electric System Operator (Operador Nacional do Sistema Elétrico - ONS) and the Energy Research Company (Empresa de Pesquisa Energética - EPE) conducted a joint study whose results had a direct impact on the energy export limits of the Brazilian North region, reinforcing the attention to the bipoles in HVDC $800 \mathrm{kV}$, one of them being the Xingu-Rio Transmission System.

The venture's Permitted Annual Revenue (Receita Anual Permitida - RAP) is approximately R\$ 1.1 billion/year (US\$ 0.35 billion/year), or approximately R 91.6 million/month (US\$ $29.1 \mathrm{million} / \mathrm{month}$ ), that is, every month the project delays its start-up in relation to the term of 50 months, this resource is not paid to the entrepreneur permanently. Thus, if the venture delays 4 months, the revenue value of R $\$ 366.6$ million (US\$ 116.4 million) will not be permanently paid to the entrepreneur.

Finally, it can be observed that the delay in relation to the concession contract schedule, because of uncertainties in the planning stage of the environmental licensing (until the Preliminary License), once again influences investors' payback, as well as the availability of the venture for the society. If the environmental impact study were carried out prior to the concession, in advance, these delay risks could have been avoided.

\section{Conclusions and Recommendations}

Environmental licensing is an arena of heated discussions among various actors (entrepreneurs, environmental agencies, intervening agencies, etc.). The constant updates in the rite procedures for the environmental licensing of transmission systems are attempts to avoid delays and risks.

It was presented that the following environmental criteria (Indigenous, Quilombola, Caves, Forests, Hydric bodies, Settlements, Permanent Preservation Area, Archaeological) are important for decision making on the feasibility of the enterprises, as well as their optimization route, supported by Brazilian legal landmarks.

The uncertainties surrounding the environmental licensing planning stage are evidenced when comparing the scheduled deadlines for the ventures concession and the issuance of environmental licenses, resulting in high losses for entrepreneurs and for society, for not having the energy available, defying the credibility of the system reliability.

In the environmental licensing rite, the competent agency and the entrepreneur assume antagonistic positions, as the first acts for the defense of legislation and good environmental practice, and the second for the search of celerity in the issuance of environmental licenses to meet the concession contract terms. Unfortunately, both forget they are exercising their attributions and competences to serve society in the provision of electricity services with quality and coherent tariff moderateness, in respect of a healthy environment.

\section{Aknowledgements}

We thank the Federal Fluminense University, for their support in the publication of the article. This research did not receive any specific grant from funding agencies in the public, commercial, or not-for-profit sectors.

\section{References}

ABOTAH, REMAL. DAIM, TUGRUL U. Towards building a multi perspective policy development framework for transition into renewable energy. Sustainable Energy Technologies and Assessments 21 (2017) 67-88.

AKINYELE, DANIEL, O. RAYUDU, RAMESH K. Strategy for developing energy systems for remote communities: Insights to best practices and sustainability. Sustainable Energy Technologies and Assessments 16 (2016) $106-127$. 
ÁRNADOTTIR, KRISTÍN L. Participation in the Environmental Impact Assessment process. Analysis of two case studies from the energy sector in Iceland. Lunds Universitet. Sweden. 2002

BRASIL, BRAZILIAN MINISTRY OF MINES AND ENERGY, ENERGY RESEARCH COMPANY. Decennial Energy Expansion Plan 2026 / Ministry of Mines and Energy. Energy Research Company. Brasília: MME/EPE, 2015

BRASIL, BRAZILIAN MINISTRY OF MINES AND ENERGY, ENERGY RESEARCH COMPANY. Guidelines for the Elaboration of Technical Reports Regarding New Basic Network Installations. EPE-DEE-RE-001/2005-R1. May 2005. 25p.

BRASIL, BRAZILIAN MINISTRY OF MINES AND ENERGY. Joint study of EPE and ONS. EPE-DEE-NT-034/2016 and ONS NT-021/2016. Impact analysis of the delay of the works of Abengoa and prioritization of works. April 2016.

BRASIL, BRAZILIAN MINISTRY OF ENVIRONMENT. Ordinance MMA 421/11. It provides for the licensing and federal environmental regulation of electric power transmission systems and provides other measures.

BRASIL. Interministerial Ordinance 60/15. Establishes administrative procedures that discipline the performance of federal public administration bodies and entities in IBAMA's environmental licensing processes.

BRASIL. Law 6.938/81. Provides for the National Environmental Policy, its purposes and mechanisms of formulation and application, and other measures.

BRASIL. LEI 10.847/04 - Cria a Empresa de Pesquisa Energética - EPE e dá outras providências.

BRASIL. Resolution CONAMA 01/86. Establishes the EIA / RIMA as an Environmental Impact Assessment tool. Defines minimum EIA content.

BRASIL. Resolution CONAMA 237/97. Regulates the Environmental Licensing procedure.

BOLEA, MARIA TERESA ESTEVAN; Environmental impact assessment. MAPFRE Foundation. Madrid, 1984.

BONATTO, F. ET AL. Incorporação da dimensão ambiental ao Planejamento do Sistema de Transmissão Brasileiro - Projeto Ambientrans. CEPEL- CIER Temário 7: Metodología de evaluación ambiental de lós planes de expansión. Rio de Janeiro. 10p. 2004.

CAMPOS, O. L. Estudo de caso sobre impactos ambientais de linhas de transmissão na Região Amazônica. Rio de Janeiro: BNDES Setorial, n. 32, p. 231-266, 2010.

CARDOSO JR., RICARDO ABRANCHES FELIX. Environmental licensing process of power transmission in Brazil update analysis: Case study of the Madeira transmission system / Ricardo Abranches Felix Cardoso Junior - Rio de Janeiro: UFRJ/COPPE, 2014

CARDOSO JR., RICARDO ABRANCHES FELIX, ET AL. Environmental licensing process of power transmission in Brazil update analysis: Case study of the Madeira transmission system. Energy Policy 67 (2014) 281-289. 2014

CONCREMAT ENGINEERING AND TECHNOLOGY. Environmental Impact Study and Environmental Impact Report of the Xingu - Rio Transmission System. 2016.

DE CASTRO, N. J., MARTELO, ERNESTO; DASSIE, ADRIANA MARIA. The mismatch between transmission and generation of electricity in Brazil. Canal Energia. GESEL/UFRJ, 2012.

EUROPEAN UNION. Directive 85/337/CEE. Concerning the evaluation of the effects of certain public and private projects on the environment. 1985.

LEME MACHADO, PAULO AFFONSO. Brazilian Environmental Law. 21ㅡㄹ Edition. Malheiros Editors. 2013.

MAGRINI, ALESSANDRA. Environmental Impact Assessment. In: Margulis, S.. Environment. Technical and economic aspects. Brasília: IPEA/PNUD, 1990. 
MILARÉ, ÉDIS. Environmental Law. São Paulo. RT. 2001.

MOREIRA, IARA VEROCAI DIAS. Environmental Impact Assessment, Technical Assistance from the FEEMA Presidency. Rio de Janeiro, 1985.

OLIVEIRA, ANTÔNIO INAGÊ DE ASSIS. Introduction to Brazilian environmental legislation and environmental licensing. Rio de Janeiro: Lumen Júris. 2005

NATIONAL OPERATOR OF THE ELECTRIC SECTOR (ONS). Map of the National Interconnected System. 2017.

SÁNCHEZ, LUIZ ENRIQUE. Environmental Impact Assessment: Concepts and methods / São Paulo. Oficina de Textos, 2008. 177

SANTOS, ARTUR WILLCOX DOS. Environmental licensing and integrated planning of electricity generation and transmission: limitations and challenges for Brazil. Master's Dissertation - PUC / Rio, Post-Graduation Program in Urban and Environmental Engineering, 2017.

TRENNEPOHL, CURT. TRENNEPOHL, TERENCE. Environmental licensing. - 5ª Edição Ed. Impetus. 2013.

WATHERN, PETER. Environmental Impact Assessment: theory and practice. Environmental Impact Analysis. Taylor \& Francis Group. 1988. 